\title{
Baseline Widal Agglutination Titre in Apparently Healthy Nepalese Blood Donors
}

\author{
${ }^{1}$ Tankeshwar Acharya, ${ }^{2}$ Bishnu Raj Tiwari, ${ }^{3}$ Bharat Mani Pokhrel \\ ${ }^{1}$ Patan Academy of Health Sciences (PAHS), Lalitpur, Nepal \\ ${ }^{2}$ School of Health and Allied Sciences, Pokhara University, Kaski, Nepal \\ ${ }^{3}$ Institute of Medicine (IOM), Tribhuvan University, Maharajgunj, Kathmandu, Nepal
}

\begin{abstract}
Widal test could be the useful tool for the diagnosis of Typhoid fever, provided the results of Widal test are correctly interpreted. Interpretation of Widal test is based on the baseline titre of healthy population of particular geography. This study was carried out in view to determine Widal baseline titre of healthy blood donors in Nepal from June to December 2009, in Nepal Red Cross Central Blood Transfusion Service and Department of Microbiology of National College. Blood samples were collected from 490 apparently healthy blood donors from 5 different developmental regions. Widal agglutination titre was determined with the use of standard technique as per the manufacture's instruction. Of the total 490 blood samples, 35.1\% (172) samples showed anti $O$ titre $\geq 1: 20$ against serotype Typhi, similarly 32.9\% and 24.1\% samples had titre $\geq 1: 40$ and $\geq 1: 80$ respectively. About $10.4 \%$ population had anti-O titre $\geq 1: 160$. Of the total blood samples, 29.4\% (143) samples showed anti $H$ titres $\geq 1: 20$ against serotype Typhi, similarly $26.1 \%$ had a titre $\geq 1: 40$, and $16.3 \%$ had a titre $\geq 1: 160$. Anti-H titres $\geq 1: 20$ were found in serotype Paratyphi A (6.3\%) and Paratyphi B (3.1\%). Both ' $O$ ' and ' $H$ 'agglutination titre varied according to the geographical location. This study showed high titres $>1: 160$ for serotype Typhi, 'O'(10\%) and ' $H$ ' (16.3\%) of widal agglutinin in apparently healthy individuals. This necessitates larger rise in widal agglutinin titre for a 'positive' diagnosis. Widal test had played a major role in the diagnosis of typhoid fever in the past, but its diagnostic significance is less now.
\end{abstract}

Keyword: Widal test, Enteric fever, Nepal

Corresponding author: Tankeshwar Acharya, Patan Academy of Health Sciences (PAHS), Lalitpur, Nepal.

E-mail: tankeshwarachary@gmail.com

\section{INTRODUCTION}

Enteric fever is an endemic and major public health problem in Nepal. In 2067/68 about 506183 Enteric fever (Typhoid and Paratyphoid fever) cases were reported and it is ranked as top 4 reasons for hospitalization in Nepal. ${ }^{1}$ Culture of blood is the gold standard for the diagnosis of enteric fever but such facilities is limited only in the major hospitals. In Nepal, where patient visits the hospital during late in the course of disease, and also take antibiotics as self medication prior to hospital visit, empirical treatment or treatment based solely on a Widal test is still a common practice.

In Nepal enteric fever is largely diagnosed on the basis of clinical signs and symptoms in the outpatient clinics $^{2}$ but the clinical diagnosis of enteric fever is often inaccurate. ${ }^{3} \mathrm{~A}$ single Widal test done on an acute phase serum is the most commonly used test in Nepal. A number of reports from developing countries showed that if the results of Widal test are interpreted correctly, Widal test still has diagnostic utility ${ }^{4-6}$ but other researchers disputed the diagnostic significance of single Widal test. ${ }^{7-10}$ Widal test is easy, inexpensive, and relatively noninvasive and it is the single most frequently used test for the diagnosis of enteric fever, in situations where blood cultures can not be obtained / not available. ${ }^{11}$

In endemic places, interpretation of the Widal test hinges on knowledge of the seroprevalence of positive titres among healthy members of population. ${ }^{6}$ These titres vary among endemic areas and with time. So each country or region should have regular studies to up to date baseline titre, so that better judgment based on the prevailing agglutinin titres could be made. ${ }^{6,8}$

The prevailing economic and social circumstances in our country are unlikely to change in the near future. Consequently, the problems of self-medication as well as lack of adequate facilities for culture techniques are likely to continue for some time. There are less chances of adoption of newer diagnostic techniques for the diagnosis of enteric fever. So this study is carried out to find the baseline agglutinin titre in apparently healthy population living in different parts of Nepal. The findings of this study will help clinicians that must often rely solely upon the results of single Widal test in making diagnosis of Enteric fever.

\section{MATERIALS AND METHODS}

The study was performed in Nepal Red Cross Central Blood Transfusion Service and Department of Microbiology of National College, Kathmandu, Nepal from June to December 2009. Study population comprised of healthy voluntary blood donors of 18 to 60 years of age who gave to the Blood Transfusion Service (BTS) of Nepal Red Cross society in Kathmandu, Butwal, Nepalgunj, Dhangadi and Biratnagar. The widal agglutination test was performed using standardized suspension of $S$. enterica serotype Typhi ' $\mathrm{O}$ ' and ' $\mathrm{H}$ ' and S. enterica serotype Paratyphi A ' $\mathrm{H}$ ' and 
S. enterica serotype Paratyphi B 'H' antigen purchased from Tulip Diagnostics (P) Ltd. India. Quality control was done using the positive polyspecific control of the same dilutions as the test sample. Normal saline was used for a negative control. Data analysis was performed by using Microsoft excel and computer software package, Statistical Package for the Social Sciences (SPSS) 11.5 version.

\section{RESULTS}

A total of 490 serum samples were analyzed. Out of 490 serum samples, the serum sample from male were $431(88 \%)$ and from female were $59(12 \%)$. The age of the study population ranged form 18 years to 60 years.

Of the tested 490 serum samples, a significant number of 248 (50.6\%) were found to be Widal agglutination test positive (agglutinin titre $(\geq 1: 20))$ with atleast one of the tested antigens $(\mathrm{O}, \mathrm{H}, \mathrm{AH}$ and $\mathrm{BH})$. None of the sample showed agglutinin titre of $(\geq 1: 20)$ for the all the tested antigen.

Table 1: Distribution of Widal agglutinin titre $(\geq 1: 20)$ in the Studied Population

\begin{tabular}{|c|l|r|}
\hline S.N. & Titre & Frequency (Percent) \\
\hline 1 & Negative & $242(49.4 \%)$ \\
\hline 2 & O positive only & $83(16.9 \%)$ \\
\hline 3 & H positive only & $49(10.0 \%)$ \\
\hline 4 & O and H positive & $72(14.7 \%)$ \\
\hline 5 & O,H and AH positive & $7(1.4 \%)$ \\
\hline 6 & O,H and BH positive & $7(1.4 \%)$ \\
\hline 7 & AH positive only & $13(2.7 \%)$ \\
\hline 8 & BH positive only & $6(1.2 \%)$ \\
\hline 9 & H and AH positive & $8(1.6 \%)$ \\
\hline 10 & O and AH positive & $2(0.4 \%)$ \\
\hline 11 & O, AH and BH positive & $1(0.2 \%)$ \\
\hline 12 & Total & $490(100 \%)$ \\
\hline
\end{tabular}

Geographical variation of $\mathrm{O}$ agglutinin titre was assessed and it was found that highest percentage of population from Dhangadi carried all the tested O agglutinin titres. Only $10.7 \%$ of studied population from Butwal carried $\mathrm{O}$ agglutinin titre of $\mathrm{O} \geq 1: 80$ and only $1.2 \%$ of the same population carried $\mathrm{O}$ agglutinin titre of $\mathrm{O} \geq 1: 160$.

Table 2: Geographical variation of $\mathrm{O}$ agglutinin titre

\begin{tabular}{|l|c|l|c|c|c|c|c|}
\hline Place & \multirow{2}{*}{$\begin{array}{c}\text { Total } \\
\text { cases }\end{array}$} & $\begin{array}{c}\text { Negative } \\
\text { cases } \\
\end{array}$ & & \multicolumn{5}{|c|}{ End titre occurred in percentage of population } \\
\cline { 4 - 8 } & & $\mathrm{O} \geq 1: 20$ & $\mathrm{O} \geq 1: 40$ & $\mathrm{O} \geq 1: 80$ & $\mathrm{O} \geq 1: 160$ & $\mathrm{O} \geq 1: 320$ \\
\hline Biratnagar & 100 & 58 & 42.0 & 40.0 & 29.0 & 12.0 & 0.0 \\
\hline Kathmandu & 110 & 67.3 & 32.7 & 32.7 & 30.0 & 12.7 & 0.0 \\
\hline Butwal & 84 & 69 & 31.0 & 28.6 & 10.7 & 1.2 & 0.0 \\
\hline Nepalgunj & 92 & 76.1 & 23.9 & 20.7 & 14.1 & 5.4 & 0.0 \\
\hline Dhangadi & 104 & 55.8 & 44.2 & 40.4 & 32.7 & 18.3 & 1.9 \\
\hline $\begin{array}{l}\text { Total } \\
\text { (Nepal) }\end{array}$ & 490 & 64.9 & 35.1 & 32.9 & 24.1 & 10.4 & 0.4 \\
\hline
\end{tabular}

The percentage of individuals having $\mathrm{H}$ agglutinin titre of $\geq 1: 80$ varied from $5.8 \%$ being lowest in Dhangadi to the $30 \%$ being highest in Kathmandu (Table 3). Highest percentage of population from Kathmandu also had $\mathrm{H}$ agglutinin titre of $\mathrm{H} \geq 1: 160$ and $\mathrm{H} \geq 1: 320$, being $30 \%$ and $20 \%$ respectively.

Table 3: Geographical variation of $H$ agglutinin titre

\begin{tabular}{|l|c|c|c|l|l|l|l|}
\hline \multicolumn{2}{|c|}{ Place } & $\begin{array}{c}\text { Total } \\
\text { cases }\end{array}$ & $\begin{array}{c}\text { Negative } \\
\text { cases } \\
\text { 20) }\end{array}$ & \multicolumn{5}{|c|}{$\begin{array}{c}\text { End titre occurred in percentage of } \\
\text { population }\end{array}$} \\
\cline { 3 - 8 } & & & $\mathrm{H} \geq 1: 20$ & $\mathrm{H} \geq 1: 40$ & $\mathrm{H} \geq 1: 80$ & $\mathrm{H} \geq 1: 160$ & $\mathrm{H} \geq 1: 320$ \\
\hline Biratnagar & 100 & 66 & 34.0 & 30.0 & 22.0 & 14.0 & 8.0 \\
\hline Kathmandu & 110 & 53.6 & 46.4 & 44.5 & 30.0 & 20.0 & 5.5 \\
\hline Butwal & 84 & 61.9 & 38.1 & 32.1 & 14.3 & 7.1 & 2.4 \\
\hline Nepalgunj & 92 & 83.7 & 16.3 & 16.3 & 7.6 & 5.4 & 4.3 \\
\hline Dhangadi & 104 & 88.5 & 11.5 & 6.7 & 5.8 & 4.8 & 3.8 \\
\hline Total (Nepal) & 490 & 70.6 & 29.4 & 26.1 & 16.3 & 10.6 & 4.9 \\
\hline
\end{tabular}

Highest percentage of population from Kathmandu and Dhangadi had $\mathrm{O}$ and $\mathrm{H}$ agglutinin titre of $\geq 1: 160$ respectively. More than $10 \%$ of individuals from Biratnagar, Kathmandu had both $\mathrm{H}$ and $\mathrm{O}$ agglutinin titre of $\geq 1: 160$. Least percentage of individuals from Butwal and Dhangadi had $\mathrm{O}$ and $\mathrm{H}$ agglutinin titre of $\geq 1: 160$ respectively.

$\mathrm{O}$ agglutinin titre of $\geq 1: 320$ was seen only in the population of Dhangadi but $\mathrm{H}$ agglutinin titre of 1:320 was seen in varying percentage of population, being highest in Biratnagar (8\%) and lowest in Butwal (2.4\%).

Out of total samples, only $6.3 \%$ showed AH agglutination of $\geq 1: 20$. Highest percentage of population (10\%) from Kathmandu showed AH titre of $\geq 1: 20$. AH titre of $\geq 1: 80$ were seen in $7.3 \%$ population of Kathmandu, in the rest of the population, the titre was below $5 \%$.

Table 4: 'AH' agglutinins in normal population of different geographical region

\begin{tabular}{|l|c|c|c|c|c|}
\hline \multirow{2}{*}{ Place } & \multicolumn{5}{|c|}{ End titre occurred in percentage of population } \\
\cline { 2 - 6 } & $\mathrm{AH} \geq 1: 20$ & $\mathrm{AH} \geq 1: 40$ & $\mathrm{AH} \geq 1: 80$ & $\mathrm{AH} \geq 1: 160$ & $\mathrm{AH} \geq 1: 320$ \\
\hline Biratnagar & 4.0 & 4.0 & 2.0 & 1.0 & 0.0 \\
\hline Kathmandu & 10.0 & 9.1 & 7.3 & 4.5 & 2.7 \\
\hline Butwal & 6.0 & 4.8 & 2.4 & 0.0 & 0.0 \\
\hline Nepalgunj & 4.3 & 4.3 & 1.1 & 0.0 & 0.0 \\
\hline Dhangadi & 6.7 & 5.8 & 4.8 & 3.8 & 2.8 \\
\hline Total (Nepal) & 6.3 & 5.7 & 3.7 & 2.0 & 1.2 \\
\hline
\end{tabular}

In the studied population, only $3.1 \%$ of population showed BH titre of $\geq 1: 20$. Highest percentage of samples (5\%) from Biratnagar showed BH titre of $1: 20$. BH titre of $\geq 1: 40$ were seen in insignificant percentage of the population i.e. less than $5 \%$. Out of total samples, only $\mathrm{O}$, only $\mathrm{H}$ and both $\mathrm{O}$ and $\mathrm{H}$ titre of 1: 80 was found in $15.7 \%, 7.8 \%$ and $8.2 \%$ of population. Samples showing O titre of 1:160 were only $7.6 \%$ where as $8.0 \%$ of samples showed $H$ titre of $1: 160$. The samples 
showing titre with both $\mathrm{O}$ and $\mathrm{H}$ agglutinin were only $2.7 \%$. None of the samples showed both $\mathrm{O}$ and $\mathrm{H}$ titre of 1:320.

Table 5: Number and percentage of sera with end titre ( $\mathrm{O}$ and $\mathrm{H})$

\begin{tabular}{|l|l|l|l|}
\hline \multirow{2}{*}{} & \multicolumn{3}{|c|}{$\begin{array}{c}\text { End titre occurred in percentage of } \\
\text { population }\end{array}$} \\
\cline { 2 - 4 } & $1: 80$ & $1: 160$ & $1: 320$ \\
\hline Both O and H titre negative & $335(68.4)$ & $401(81.8)$ & $463(94.5)$ \\
\hline Only O titre positive & $77(15.7)$ & $37(7.6)$ & $2(.4)$ \\
\hline Only H titre positive & $38(7.8)$ & $39(8.0)$ & $25(5.1)$ \\
\hline Both O and H titre positive & $40(8.2)$ & $13(2.7)$ & $0(0)$ \\
\hline
\end{tabular}

\section{DISCUSSION}

Out of total 490 serum samples, about $50 \%$ sample showed antibodies against salmonella antigens with varying antibody titre. This may be due to the higher endemicity of enteric fever in Nepal which is sustained because of the poor sanitation, low standard of living and lack of medical facilities. ${ }^{12}$ This may also be due to the repeated subclinical infections with either of Escherichia, Shigella, Citrobacter or Proteus sps which shared common $\mathrm{O}$ or $\mathrm{H}$ antigens with Salmonella spp. ${ }^{13,14}$

Variable titre with both $\mathrm{O}, \mathrm{H}$ and $\mathrm{AH}$ or $\mathrm{BH}$ antigens was found, this might be due to the cross infection of Salmonella enterica serotype Typhi and Salmonella enterica serotype Paratyphi A and /or B. Lower antibody titre against AH and BH antigens highlighted the lower endemicity of Paratyphi infection compared with typhi infection and/or low antibody response against paratyphi infection.

This study clearly showed that in an endemic area such as Nepal, $S$. enterica serotype Typhi agglutinins against both $\mathrm{H}$ and $\mathrm{O}$ antigens may be present in the normal population at titres up to or greater than 1:320. Out of the total serum samples, we found $\mathrm{O}$ and $\mathrm{H}$ agglutinin titre of $\geq 1: 160$ in $10.4 \%$ and $10.6 \%$ of blood donors respectively. $\mathrm{H}$ agglutinin at a titre of 1:320 was found in $4.9 \%$ of blood donors. This presence of significant agglutinin titre in healthy individuals decreases the specificity of the Widal test, leading to misdiagnosis and mismanagement of the patient. In a similar type of study, $15 \%$ of the individuals had anti-O antibody titres of $\geq 1: 80$ and $16 \%$ had anti-H antibody titres of $\geq 1: 160 .{ }^{15}$ A study by Pang and Puthucheray found, $\mathrm{O}$ and $\mathrm{H}$ agglutinins titres of $\geq$ $1: 160$ in $5 \%$ and $2 \%$ of non-infected individuals. ${ }^{6}$

We found geographical variation of both $\mathrm{O}$ and $\mathrm{H}$ Widal agglutinin titre. $\mathrm{H}$ agglutinin titre varied greatly compared with $\mathrm{O}$ agglutinin titre. $\mathrm{O}$ agglutinin titre of 1:160 was occurred only in $1.2 \%$ of the healthy blood donors from Butwal indicating that $O$ titre of $1: 160$ can be used as a diagnostic titre for Butwal. At a titre of 1:80, lowest percentage of $\mathrm{H}$ agglutinin was found in the serum samples of healthy blood donors from Dhangadi. This result showed that $\mathrm{H}$ agglutinin titre $>1: 80$ can be of diagnostic value for that community. Highest $\mathrm{H}$ agglutinin titre was found in the blood samples taken from Biratnagar.

The currently used cutoff value for anti-H titre against $S$. enterica serotype Paratyphi A in Nepal is $\geq 1: 80$. Our study found that $3.7 \%$ of individuals had anti-H agglutinin titre of $\geq$ 1:80 to salmonella enterica serotype Paratyphi A. Our study found that $\mathrm{AH}$ agglutinin titre is increasing in the population when compared with the similar study done in Nepal. ${ }^{15}$ This may be due to an increase in general population antibody levels caused by the changing pattern of Salmonella enterica serotype Paratyphi A in the community. The seroprevalence of Salmonella enterica serotype Paratyphi B was found quiet low in the whole studied population.

The percentage of samples showing agglutination with both $\mathrm{O}$ and $\mathrm{H}$ antigens at a titre of 1:80 were $8.2 \%$ where as only $2.7 \%$ of the total samples were positive with both $\mathrm{O}$ and $\mathrm{H}$ agglutinin at a titre of 1:160. This showed that when both $\mathrm{O}$ and $\mathrm{H}$ antigens are considered together, titre of 1:160 is sufficient to make presumptive diagnosis of enteric fever. From the study done in Kathmandu by Pokhrel et. al., found that $12 \%$ of individuals had an anti- $\mathrm{O}$ titre of 1:80 and anti$\mathrm{H}$ titre of $1: 160 .{ }^{15}$ Based on this they recommended cut off levels against S.enterica serotype Typhi to $>1: 80$ for anti - O and $>1: 160$ for anti- $\mathrm{H}$ titres for Nepal. From a similar type of study by Zailani et al the baseline and significant titre to $\mathrm{S}$. typhi/paratyphi for both $\mathrm{O}$ and $\mathrm{H}$ antibody is $1: 80$ and $\geq 1: 160$ respectively in Ile-Ife, Nigeria. ${ }^{16}$

In this study we found that about $10.5 \%$ of individuals had both $\mathrm{O}$ and $\mathrm{H}$ agglutinin titre of 1:160. Based on this finding we recommend that it will be more appropriate to change currently used cut off titre levels against $\mathrm{S}$. enterica sertotype Typhi to $>$ 1:160 for both $\mathrm{O}$ and $\mathrm{H}$ titres for Nepal.

\section{CONCLUSION}

Salmonella agglutinins are common among apparently healthy blood donors in Nepal with wide variation in baseline Widal agglutinin titre. Both $\mathrm{O}$ and $\mathrm{H}$ agglutinin titre $>1: 160$ could be diagnostically significant in the presumptive diagnosis of enteric fever in Nepal. When blood culture facility is not available or impractical, Widal test can be used provided the results are interpreted with relevant clinical findings and prevailing $\mathrm{O}$ and $\mathrm{H}$ agglutinin titres in local population. But with this need of larger rise in widal agglutinin titre for a 'positive' diagnosis the diagnositic value of the Widal test is less. 


\section{ACKNOWLEDGEMENT}

We express our gratitude to all the staffs of Nepal Red Cross Blood Transfusion Service and National College for their help during sample collection and processing. We are also thankful to Mrs. Sarita Manandhar and Mrs. Basuda Shrestha for their support.

\section{REFERENCES}

1. DoHS. Annual Report Kathmandu: 2067/68 (2010/2011).

2. Biswas R, Dhakal B, Das RN, Shetty KJ. Resolving diagnostic uncertainty in initially poorly localizable fevers: a prospective study. International journal of clinical practice. 2004; 58(1):26-8. Epub 2004/03/05.

3. Levine MM, Grados O, Gilman RH, Woodward WE, Solis-Plaza R, Waldman W. Diagnostic value of the Widal test in areas endemic for typhoid fever. The American journal of tropical medicine and hygiene. 1978; 27(4):795-800. Epub 1978/07/01.

4. Kulkarni ML, Rego SJ. Value of single Widal test in the diagnosis of typhoid fever. Indian pediatrics. 1994; 31(11):1373-7. Epub 1994/11/01.

5. Mohammed I, Chikwem JO, Gashau W. Determination by Widal agglutination of the baseline titre for the diagnosis of typhoid fever in two Nigerian states. Scandinavian journal of immunology Supplement. 1992; 11:153-6. Epub 1992/01/01.

6. Pang T, Puthucheary SD. Significance and value of the Widal test in the diagnosis of typhoid fever in an endemic area. Journal of clinical pathology. 1983; 36(4):471-5. Epub 1983/04/01.

7. Schroeder SA. Interpretation of serologic tests for typhoid fever. JAMA : the journal of the American Medical Association. 1968; 206(4):839-40. Epub 1968/10/21.

8. Olopoenia LA, King AL. Widal agglutination test - 100 years later: still plagued by controversy. Postgraduate medical journal. 2000; 76(892):80-4. Epub 2000/01/22.

9. Reynolds DW, Carpenter RL, Simon WH. Diagnostic specificity of Widal's reaction for typhoid fever. JAMA : the journal of the American Medical Association. 1970; 214(12):2192-3. Epub 1970/12/21.

10. Aquino RL, Lansang MA, Quimpo VS, Sombrero LT, Saniel MC. Evaluation of a single Widal test in the diagnosis of enteric fever. The Southeast Asian journal of tropical medicine and public health. 1991; 22(3):375-9. Epub 1991/09/01.

11. Willke A, Ergonul O, Bayar B. Widal test in diagnosis of typhoid fever in Turkey. Clinical and diagnostic laboratory immunology. 2002; 9(4):938-41. Epub 2002/07/03.

12. Karkey A, Aryjal A, Basnyat B, Baker S. Kathmandu, Nepal: still an enteric fever capital of the world. Journal of infection in developing countries. 2008; 2(6):461-5. Epub 2008/01/01.

13. Parry CM, Hoa NT, Diep TS, Wain J, Chinh NT, Vinh H, et al. Value of a single-tube widal test in diagnosis of typhoid fever in Vietnam. Journal of clinical microbiology. 1999; 37(9):2882-6. Epub 1999/08/17

14. Colle JG FA, Marmion BP, Simmons A. Mackie and Mc Cartney Practical Medical Microboiology. New York: Churchill Livingston 1996:389

15. Pokhrel BM, Karmacharya R, Mishra SK, Koirala J. Distribution of antibody titer against Salmonella enterica among healthy individuals in nepal. Annals of clinical microbiology and antimicrobials. 2009; 8:1. Epub 2009/01/09.

16. Zailani SB, Oyelese AO, Aboderin AO. Determination of baseline antibody titre to S. typhi/paratyphi in Ile-Ife, Nigeria. African journal of medicine and medical sciences. 2003; 32(3):307-10. Epub 2004/03/20 